\title{
Activities and Strategies for the Inclusion of a K-12 Educational Component in Digitization Grant Projects of Academic Libraries
}

By Linda Teel

\begin{abstract}
:
This article seeks to explore and discuss activities and strategies for including a K-12 educational component in digitization grant projects in academic libraries. The article is based on cases studying the K-12 educational component of the three following grants awarded to East Carolina University Joyner Library by North Carolina Exploring Cultural Heritage Online (NC ECHO) grant program: Digitizing Eastern North Carolina History, Fiction and Artifacts: The Eastern North Carolina Digital Library (http://digital.lib.ecu.edu/historyfiction/), Seeds of Change: The Daily Reflector Image Collection (http://digital.lib.ecu.edu/reflector/), and Ensuring Democracy Through Digital Access: North Carolina Government Publications Collection (beta testing). Planning, budgeting, implementation, promotion and lessons learned are discussed offering first-hand experiences in effective methods to integrate activities and strategies into digitization projects providing access to useful resources for all users with a focus on K-12 educators and students. The author's interest in this topic is based on cumulative experiences of involvement in the listed digitization grant projects as a private investigator and as an educational consultant of the above grants. Lessons learned are highlighted providing readers with specific, valuable details for consideration to improve future digitization projects.
\end{abstract}

\section{Introduction}

In the American Association of School Librarians Standards for the $21^{\text {st }}$-Century Learner (2007), the development of -eommon beliefs" has placed major importance on key elements which are considered vital in preparing $21^{\text {st }}$ century learners for success in tomorrow's world. Such -ommon beliefs" include equipping learners with skills of inquiry and technology providing a framework for learning which is crucial for future employment. Equally important to inquiry and technological skill development is providing equitable access to information so that all learners can use and integrate information in learning.

With such emphasis placed on these important beliefs, the need to include K-12 educational components in digitization projects within the academic library environment is one that should be highly considered. In order to become independent learners, students must have access to reliable information allowing the development of inquiry and technological skills in their quest for knowledge, growth, and understanding. Through digitization collections, K-12 teachers have the opportunity to energize classroom instruction and re-engage students as they seek to attain a higher level of learning (Adams, 2005).
Collaboration between academic libraries and K12 educators for the purpose of developing educational components in digitization projects extends valuable opportunities to teachers and students preparing them to meet the demands of a technologically changing world. In a recent study by Rideout, Foehr, and Roberts (2010), the report stated that young people (ages 8-18) live mediasaturated lives spending nearly 7 hours and 38 minutes per day using media. It was further noted that while young people are using media more than a quarter of the day (29\%) they are proficient in multi-tasking using two or more media simultaneously. Digital resources can provide alternative methods to the traditional text-based learning which, in some instances, has disengaged young people from learning. While school libraries are essential to the development of learning at the K-12 level (AASL, 2007), academic libraries have an opportunity to open the door of collaboration in order to become involved in and contribute to the outcome of future students and users.

\section{Background Information}

Information provided by the author in this article is based upon research and experiences gained

Education Libraries, Volume 33, Number 2, Winter 2010 
while serving as the principle investigator and/or educational consultant for three digitization grants awarded to East Carolina University Joyner Library by North Carolina Exploring Cultural Heritage Online (NC ECHO) covering the dates of 2004 through 2012. Appendix A: A Comparison of History and Accomplishments of K-12 Educational Components of Digitization Grants Awarded To East Carolina University Joyner Library provides a brief overview of each grant including key elements relevant to the development of the K-12 educational component for each project. While the digitization of materials for each grant as noted in - Apendix A" and was a key component in the overall planning of all three grants as well as in the success of the educational component of each grant, it was not the responsibility of the educational component planning committee. Web addresses are provided to encourage readers to visit the web resources for further information. Activities and strategies used to develop the educational components of these grants are described in full detail in the article providing an insight into the process of developing a K-12 educational component for inclusion into future academic digitization projects.

\section{Planning}

Prior to considering any activities or strategies, initial planning for the inclusion of a successful K12 educational component in a digitization grant project at an academic library includes collaboration and formation of partnerships. Through partnerships, libraries discover opportunities to improve services as well as enhance and expand access to collections while meeting the needs of changing patrons (Buxton and Gover, 2003). The formation of partnerships is critical in producing a digital resource because, once formed, all partners embark on a long-term relationship which requires open communication, cooperation and input to be successful.

Climate and timing are factors of consideration. Partners must be open and committed to the partnership realizing that serious allocations of time, in some cases years, are required to make the project successful. Each partner must feel a sense of ownership based on contributions, needs and desired outcomes. Identifying educational partners is best determined by the content and the desired outcomes of the digitization grant project. Educational partners may include individuals from: College of Education programs, Curriculum Materials Centers, State Departments of Instruction, museums, local agencies as well as homeschoolers, public and private K-12 schools. Once partners are identified and committed to the project, letters of support along with a collaborative written document outlining the role of each partner, and a timeline including dates and events of proposed accomplishments are agreed upon and completed. Collaboration and partnerships among educational institutions show grant funding agencies that applicants are seeking not only to improve their immediate community but provide benefits to a cross-sectional population of their expanded community. At this point, planning and coordination for long-range plans begins to mutually benefit all partners (Honig-Bear, 2001).

The time required to write and develop a highquality grant application is often underestimated. Therefore, it is essential to finalize partners quickly and begin meeting as a team to collaborate on activities and strategies for the educational component of the project. If the entire educational team cannot be present at grant meetings, then a representative of the team must be present and fully engaged throughout the entire grant application process. Callison (1997) projects that open and welcomed communication in conjunction with commitment and involvement from all partners leads to decision-making that will produce follow-up action, support and successful cooperation.

In many cases, digitization grant projects with educational components require 2-3 years for completion; therefore, initial planning is directly related to the success and outcome of the overall digitization project. Activities and strategies are developed as soon as the planning process begins in order to determine appropriate funding for implementation. Educational partners possess the expertise needed to develop the activities and strategies best suited for inclusion in the 
educational component assuring the success of the project. Activities and strategies vary depending on several factors: the level of usability of the digitized materials in conjunction with the ability of integration into the school curriculum and standards, the amount of funding available, and the amount of time for completion of the grant project.

Based on the author's involvement with educational teams, the following activities produced successful outcomes in digitization grant projects: budgeting, designing an education portal for the web resource, conducting teacher focus groups, developing cross-curricular activities and lesson plans for K-12 classrooms, and marketing/promoting the project as a classroom tool to educators.

\section{Budgeting}

In order to plan and develop a K-12 educational component in any digitization grant, the development of a realistic budget is directly related to the success of the project. The budget includes funds that support and implement the components in a professional and useful manner. The educational planning team is responsible for developing the budget carefully reviewing each area to ensure that all needs are addressed and included. Research is conducted and information gathered to analyze and determine the costs of proposed focus groups, workshops, travel, marketing and promotion as well as essential equipment to conduct focus groups, workshops and presentations in regard to marketing and promotion.

Once the budget has been developed, each team member reviews each line item carefully comparing the budget to the educational component of the grant proposal to assure that sufficient funding is requested to realistically obtain the goals of the educational component. While realistic budgeting is the final goal, proper analysis of needs is obtained through research and gathering information based on current and future costs. For a detailed guide in terms of budgeting for an educational component in a digitization grant, see Appendix B: Sample Budget Request for a K-12 Educational Component of a Digitization Project/Grant. It should be noted that this sample budget is only for the K-12 educational component. Separate budgets must be developed by the grant planning team to address other funding needs such as necessary equipment and personnel for the actual digitization of materials.

\section{Designing an Educational Portal}

Determining activities that produce successful outcomes of an educational component in a digitization grant project establishes the need to develop strategies enabling the activities to become reality. Designing an education portal for the web resource is based on the content of the project in conjunction with the need to search the information with ease according to user needs. Several strategies are considered in order to produce an effective web design portal for educators and K-12 students. The first strategy involves designing the portal with the specific needs and interests of the users in mind. A customized and personalized approach to portals provides users with a familiar and highly useful environment extending the users' sense of comfort and ease in accessing resources.

The second strategy requires acquiring visual appeal to set a user-friendly atmosphere for the portal design. The design must cover a range of grade levels without being too juvenile so that it entices the user to engage. A blending of colors, simplicity, eye appeal and usability are vital in designing an effective portal. Outsourcing this strategy produces the best outcome unless a web designer is employed by the library.

The third strategy emphasizes the way the education portal offers convenience measured in regard to accessibility, speed, and responsiveness (Guenther, 2000). Saving teachers and K-12 students time is a top priority for any education portal. If teachers are unable to gain time when using the portal for classroom instruction, then the portal is ineffective and usage of the site decreases. If students find the speed and responsiveness of the portal to be unacceptable, they become frustrated and unable to locate valuable information leading them to disengage 
from the learning process and seek other alternative resources (Trotter, 1999).

The final strategy includes employing usability tests to provide valuable feedback in assessing the level of ease or difficulty in regard to user interface with the portal. Usability is defined by five quality components which provide valuable feedback. The first quality component, learnability, produces feedback based on the level of ease the users accomplishes basic tasks during first interaction with the design. Efficiency, the second component, addresses the performance speed once users are familiar with the design. Third, memorability evaluates the proficiency of the user's ability in returning to the design after a separation period. The fourth component includes assessing the number, severity and recovery of the user in relationship to errors faced while using the portal. Finally, satisfaction measures the level of pleasure the user feels when using the portal. It is extremely important to test users individually allowing them to solve as many problems on their own as possible. Any help supplied to users during a usability test contaminates the results (Nielsen, 2009).

\section{Teacher Focus Groups}

Conducting teacher focus groups is an activity for consideration in producing successful outcomes for an educational component in a digitization grant project. Powell and Single (1996) define a focus group as a group of selected individuals assembled by researchers to discuss, comment and give personal feedback on a given topic. The focus group employs guided, interactional discussion as a means of generating actions, beliefs, perceptions and attitudes used to identify potential areas of enquiry, to clarify or to improve subject matter. The underpinning focus of discussions is any method that engages the focus group in a collective activity, such as viewing a presentation, examining a website or simply debating a particular set of questions.

There are several strategies to consider when implementing a beneficial and successful focus group. First, careful organization and preparation for the focus group is crucial. Date and location of the meeting place must be established well in advance to ensure proper preparation time for submitting all paperwork required by the university. Early scheduling allows participants to be informed of the date and meeting place when they are selected so they can commit immediately to the meeting. The session lasts 90-120 minutes based on the complexity of the topic under investigation and/or the number of participants in the group. When securing a meeting location, a neutral location where participants will be unhampered and open to discussion is optimal. During the organization of the focus group, a moderator is selected. A person who is relaxed, nonjudgmental and a good listener is the best choice. The moderator is accompanied by one or two note-takers who document responses of the group including expressive body language. Advance planning is the key element to being prepared.

The second strategy involves developing the focus group interview instrument. The focus group discussion will be driven by the interview instrument. Five to seven discussion questions that are open-ended, phrased clearly and simply are ample. The questions draw upon concrete examples that illustrate the topic. If applicable, it is best to sequence questions from lesser to more sensitive or intense questions. The moderator is receptive and encourages the discussion of relevant issues that arise from participants which are not anticipated ensuring that the discussion proceeds in a normal flow (Powell and Single, 1996).

The focus group interview instrument is developed and finalized prior to initiating the third strategy, seeking proper approval from administration in order to cover all legal obligations of the university. Most universities have an Institutional Review Board. The primary function of this board is to protect the rights and welfare of human subjects engaged in research at the university, and in research conducted elsewhere by faculty, students, staff or other representatives of the university in connection with their responsibilities. The university and its researchers are required to follow procedures and submit proper documentation for approval prior to conducting

Education Libraries, Volume 33, Number 2, Winter 2010 
the research to assure the protection of all participants involved in a human subjects research project (East Carolina University, 2009). In addition to the standard documentation, the review board requires the researcher to submit the date, location, credentials of researcher, format of focus group, procedures for selecting participants as well as the focus group interview instrument for approval and review; therefore, it is essential that the focus group be organized and that the interview instrument be finalized prior to this strategy.

Strategy four involves selecting participants. Prior to beginning this strategy, the criteria for selecting participants is established and accepted by the university review board. Criterion for this strategy includes selecting individuals with shared key characteristics pertinent to K-12 education. The group consists of six to ten participants who are strangers to each other, reducing peer influence. Efforts to avoid biases during the selection process are essential while recruiting participants. The focus group comprises of participants from a diverse range of backgrounds, views and experiences. As participants are selected, they are informed of the date for the focus group meeting.

The fifth strategy is conducting the focus group session. At the beginning of the focus group, time is scheduled for informal conversation to occur. This is accomplished by providing light refreshments or lunch before the focus group begins enabling the moderator and note-taker(s) to introduce themselves to participants and to interact informally. The value of this time cannot be underestimated. It relaxes participants and fosters an atmosphere conducive to open discussion.

The final strategy is the compilation and analysis of the findings which expedites implementing changes as suggested and appropriate. This strategy is the most time-consuming stage of the focus group activity. Using the collection of raw data, it is categorized and classified into usable information for analysis of potential findings. Creative interpretation and constant comparisons are completed to detect the views among the participants and contrast the observations as related to variables within the sample population. Focus groups provide a method of acquiring rich, experiential feedback from users while enhancing the likelihood of collecting the diverse and spontaneous opinions that otherwise might not be collected (Powell and Single, 1996).

\section{Cross-Curricular Activities/Lesson Plan Development}

The development of cross-curricular activities and lesson plans for K-12 classrooms through teacher workshops integrating content of the digitized resources into standard courses of study is an important element in developing a K-12 educational component. The initial planning stage of this activity includes major factors such as: goal setting, scheduling, budgeting and developing. Incorporating the findings of the focus groups, the educators' needs and requests are addressed in the development of teacher workshops. The outcomes of workshops are directly related and crucial to future usage of the digitized resources.

Established strategies assure that high-quality, creative activities and lesson plans are produced which, in turn, provide valuable resources that encourage educators to access the digitized resources via the teacher portal.

As members of the educational grant team plan for the workshop, the first consideration is to establish goals and themes. Goals and themes set the stage for the structure of any workshop. Next, the team must seriously consider costs for implementing the workshop. The workshop budget is based on: employment of a Master Teacher to develop and conduct workshops; length and location of workshops; teacher substitutes, incentives and reimbursements for attendance; food along with workshop materials costs; and advertising workshops (Alters et al., 2001).

The essential component directly related to the success of workshops is the hiring of a recognized Master Teacher as the workshop coordinator. Written by the educational grant team, the advertisement to hire such a teacher allows the team to set the criteria in order to screen, interview and select the best candidate for this position. Once hired, the workshop coordinator develops 
the workshop based on set goals and outcomes established by the educational team. The initial development of a lesson activity/plan template by the workshop coordinator is vital in standardizing outcomes. Such standardization provides consistency for future educators as they search the site to locate desired activities as well as a standardized format for the technical team to load items onto the site providing optimal searching by grade levels, topics, and curriculum standard course of study goals.

The workshop agenda is developed by the workshop coordinator based on his/her experience and expertise in conjunction with the set goals. The educational team collaborates with the workshop coordinator to schedule workshops. The established goals and outcomes determine the length of workshops in terms of hours and/or days. Based on previous experience, a two-week workshop of ten participants produced five highquality lesson plans/activities per participant at a cost of approximately $\$ 33,925.00$ making the average cost of each lesson plan/activity approximately $\$ 678.50$.

Once length of workshops is established, other considerations include: choice of day(s) and time of year for scheduling the events. Such choices directly affect the number of applicants who apply to participate. A manageable number of teachers participating in workshops are determined by the workshop coordinator so that sufficient time can be dedicated to editing each lesson plan/activity to achieve the quality and desired number of lesson activities/plans needed. Reviewing each lesson plan/activity to evaluate the level of quality and to assure that appropriate alignments are present based upon curricular goals and objectives are responsibilities of the workshop coordinator.

With criteria and expectations established, the application for teachers to apply to attend the workshop is developed and finalized jointly between the workshop coordinator and the educational team. The application process involves the simple format of submitting an application along with two letters of recommendations from principals and/or supervisors validating credentials. The goal of the application process is to select workshop participants who have mastered the process of lesson plan/activity development allowing the workshop coordinator to focus on the use of the template to develop activities/plans integrating digitized resources into the curriculum goals and objectives. Selection of participants based on established criteria produces high-quality lesson activities/plans as the final outcome of the workshop. The application is posted on a web site and sent to appropriate teacher listservs announcing the application process and deadlines.

Financially, workshop coordinator salary, teacher substitute pay, stipends, incentives and travel reimbursements are determined during the initial planning of the educational component in order to properly establish an overall budget for the grant application. Additional charges such as: room fees for workshop locations, equipment fees, meals, snacks and costs associated with workshop materials and supplies are also included in the initial planning. Partnerships with University College of Education programs and local teachers often prove highly beneficial in determining such costs as well as in the overall planning and organizing of workshops (Alters et al., 2001).

\section{Marketing and Promotion}

Once the lesson plans and activities are finalized and accessible via the educational portal, marketing and promoting the digitized resources as classroom tools for educators become important factors in the continued success of the use of the digitized resources as well as the sustainability of the grants. While teacher workshops market and promote the digitized resources, there are several additional options that increase the access and usage of newly developed digital web sites. In order to be implemented properly and effectively, budgeting for marketing and promotion is included in the initial grant proposal and application process. An effective use of requested money for marketing is through the use of four types of media: printed, electronic, published and broadcast media. Newspaper articles, email announcements to local, state and national organizations, journal articles as well as television 
and radio advertisement/coverage are choices based on the targeted audience (Thilmany and Curtis, 2008).

Marketing and promotion are areas where partnerships prove invaluable. College of Education programs as well as local school districts are excellent partners in marketing new and free resources. Such promotions are accomplished through the use of minimal time and funding such as: printed posters, bookmarks and calendars announcing the new resources; brief presentations/ demonstrations sharing the resources during local school faculty meetings and/or system-level curricular meetings and presentations to pre-service teachers in College of Education courses where designing lesson units are required.

Other avenues for marketing and promotion include offering incentives and demonstrations via vendor booths at local, state, regional and national conferences as well as providing formal presentations of the resources at conferences. Promoting and presenting at conferences requires funding; however, such marketing produces high returns on the investment. Many local and state conferences allow non-profit groups to have a vendor booth at no charge or at reduced fees making the opportunity even more feasible. It is essential that such considerations be factored in the grant budget proposal prior to the application.

The author instituted all of the above marketing and promotion techniques in the three grants promoting the educational component of them noting that after each venue the web site statistics for the resources spiked and usage continued to increase. If the academic library has an outreach program, then marketing through that program offers continual promotion of the resources assisting in the sustainability of the grant.

\section{Lessons Learned}

As with the completion of most projects, important lessons and insight are learned which directly impact the outcome of an educational component. This was certainly the case based on the author's experience developing the K-12 educational component for the first two digitized projects funded through the NC ECHO grant program. Such insight proved valuable in the development of the K-12 educational component for the third digitization project, Ensuring Democracy through Digital Access.

A significant lesson learned was the importance of remembering anytime a project extends over twothree years staff changes occur requiring training of new team members. Training requires time and hands-on experience adding pressure to designated deadlines stated in the grant application. Such a challenge requires adjustments to complete deadlines and formal approval from the granting agency.

In regard to the development of lesson plans/activities through the use of teacher workshops, several lessons were noted. When developing teacher workshops, it is crucial to allow ample time for teachers to develop and complete lesson plans/activities. In other words, no outside homework" for teachers is mandatory. During the first digitization grant, $30 \%$ of workshop participants who did not complete lesson plans/activities during the workshops actually finished their assignments within four weeks after the workshop even when stipends were withheld until completion. During the second digitization grant, extending the workshop to two days provided additional time for teachers to complete their assignments realizing a $90 \%$ rate of completion. In the third digitization project, one teacher workshop has been designed to cover a two-week period for ten teachers to produce 50 lesson activities.

Emphasis placed on requiring workshop participants to complete an application along with two recommendations provided the K-12 educational planning team members the opportunity to review candidates selecting those highly recommended by their principals and supervisor. The improved application process provided the necessary information to select candidates based on recommendations, grade levels, regional representation and areas of curricular expertise. Such selections provided a 
diverse representation of teachers and assured a standard level of expertise whereby the workshop coordinator eliminated the need to spend extended workshop time discussing the components of a high-quality lesson plan/activity.

Upon analyzing teacher evaluation surveys from the first digitized grant project workshops, educators expressed that lesson activities were more valuable than full lesson plans. Teachers acknowledged that while an entire lesson plan is beneficial to pre-service or beginning teachers; many felt that lesson activities were more beneficial overall because most teachers use an activity from a lesson plan adapting it to fit their classroom needs.

The use of a template standardizing the lesson plan/activity process was an invaluable lesson learned. The template provided a step-by-step process that guided teachers in producing a final product that included all items needed in an easy format for reviewing and preparation to load onto the site.

Another lesson learned involved the collection of web site statistics which proved that marketing and promotion of the resources increased usage and were vital in -spreading the word" to educators. In other words, funding spent on promotion and marketing was money wellinvested.

A noteworthy and cost-saving lesson was that hiring a master teacher as the workshop coordinator saved time and repeated efforts in the workshop development process. It is highly recommended to include funding for this position because such expertise is invaluable in developing a workshop that produces the desired outcomes of high-quality lesson plans/activities useful for classrooms. Budgeting for this position was given careful consideration based on the need for professional experience in conjunction with time required to successfully lead teachers to the desired outcomes.

Finally, the most valuable lesson learned was that Teachers + Input $=$ Ownership, and Ownership +
Valuable Resources $=$ Success." It takes each team member along with everyone involved in the grant to produce the final outcome giving $100 \%$ to make any project successful.

\section{Conclusion}

The inclusion of a K-12 educational component is a worthy consideration for academic libraries when applying for digitization grants. The special collections held by academic libraries are vast and rich offering valuable resources to a diverse population of users. Through sharing and discussing experiences gained in the development of the K-12 educational components for Digitizing Eastern North Carolina History, Fiction and Artifacts: The Eastern North Carolina Digital Library; Seeds of Change: The Daily Reflector Image Collection; and Ensuring Democracy Through Digital Access: North Carolina Government Publications Collection at East Carolina University Joyner Library, activities and strategies for planning, budgeting, implementation and promotion as well as an open discussion on lesson learned during the development process provide a tested guide for consideration of inclusion in academic library digitization grants.

The value that a K-12 educational component adds to a digitization project is invaluable especially for classroom teachers and students because primary resources that were once only available via the constraints of traditional access methods become easily accessible anytime and anywhere providing avenues for creative integration of online materials in the educational setting. Such educational components offer teachers and students the availability of digitized original rare books, photographs, letters, diary entries, artwork, newspaper articles, museum artifacts, broadsides and maps for use as primary sources to enrich and extend student learning in school libraries and classrooms. 


\section{References}

Adams, Leslie. 2005. The Digitization of Learning." T H E Journal 32, no. 11: 50. Academic Search Premier, EBSCO host (accessed October 21, 2009).

Alters, Brian J., John Banister-Marx, April Gardner, Craig Nelson, Judy Scotchmoor, Eugenie Scott, and Dale Springer. 2001. ACTE Teacher Workshop Blueprint," available at http://www.ucmp.berkeley.edu/ncte/twb/index.

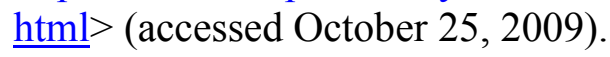

American Association of School Librarians (2007), "AASL Standards for the $21^{\text {st }}$-Century Learner," available at: http://www.ala.org/ala/mgrps/divs/aasl/guideli nesandstandards/learningstandards/AASL_Lea rning_Standards 2007.pdf $>$ (accessed October 10, 2009).

Buxton, Karen A. and Harvey R. Gover. 2003. A National Laboratory and University Branch Campus Library Partnership: Shared Benefits and Challenges from Combined Reference Services." Reference Librarian 40, no. 83/84:251-262. Academic Search Premier, EBSCO host (accessed April 1, 2009).

Callison, Daniel. 1997. Expanding Collaboration for Literacy Promotion in Public and School Libraries." Journal of Youth Services in Libraries 11, no. 1:37-49.

East Carolina University. University and Medical Center Institutional Review Board (UMCIRB) Home Page, available at $\underline{\text { http://www.ecu.edu/irb/> (accessed October }}$ 30, 2009).

Guenther, Kim. 2000. Đesigning and Managing Your Digital Library. (Cover story)." Computers in Libraries 20, no. 1:34. Academic Search Primer, EBSCOhost (accessed October 29, 2009).

Honig-Bear, Sharon. 2001. School-Public Library Partnerships in Washoe County,
Nevada." Resource Sharing \& Information

Networks 15, issue 1/2: 5-16. Academic Search Premier, EBSCO host (accessed April 1, 2009).

Nielsen, Jakob. 2009. Usability 101: Introduction to Usability." Alertbox: Current Issues in Web Usability. Nielsen Norman Group (2009) available at:

http://www.useit.com/alertbox/20030825.html.

Powell, Richard A. and Helen Single. 1996. Focus Groups." International Journal for Quality in Health Care 8, no. 5:499-504. Academic Search Premier, EBSCO host (accessed October 30, 2009).

Rideout, Victoria J., Uilla G. Foehr and Donald F. Roberts. Generation $\mathrm{M}^{2}$ : Media in the Lives of 8- to 18- Year-olds." Kaiser Family Foundation (2010), available at: http://www.kff.org/entmedia/upload/8010.pdf> (accessed April 15, 2010).

Thilmany, Dawn and Kynda R. Curtis. 2008. Marketing and Promotion Resources: Leveraging Existing Programs and Resources," Western Extension Marketing Committee (2008)m available at: http://ag.arizona.edu/arec/wemc/nichemarkets/ 06marketingandpromotionresources.pdf

Trotter, Andrew. 1999. Online Portals‘ Open a Window to the Web for Teachers." Education Week 19, no. 8:10. Academic Search Premier, EBSCOhost (accessed October 29, 2009).

Linda Teel

Associate Professor/Head of Services

Teaching Resources Center

J Y Joyner Library

East Carolina University

Greenville, North Carolina 27858-4353

Voice: 252.328 .2287

Fax: 252.328-0918

Email: teell@ecu.edu 


\section{Appendix A \\ A Comparison of History and Accomplishments of K-12 Educational Components of Digitization Grants Awarded To East Carolina University Joyner Library}

\begin{tabular}{|c|c|c|c|c|}
\hline \multicolumn{5}{|c|}{$\begin{array}{l}\text { Digitizing Eastern North Carolina History, Fiction and Artifacts: The Eastern North Carolina Digital Library } \\
\text { (http://digital.lib.ecu.edu/historyfiction/) }\end{array}$} \\
\hline $\begin{array}{l}\text { Years } \\
\text { Awarded }\end{array}$ & Budget & Digitization & $\begin{array}{l}\text { Educational } \\
\text { Resources }\end{array}$ & $\begin{array}{l}\text { Promotion/ } \\
\text { Marketing }\end{array}$ \\
\hline $\begin{array}{l}2004- \\
2007\end{array}$ & $\$ 484,907.00$ & $\begin{array}{l}60,000 \text { pages } \\
\text { digitized } \\
700 \text { XML encoded } \\
\text { documents } \\
\text { processed; } \\
60,900 \text { images } \\
\text { converted } \\
\text { for Zoomify; } 900 \\
\text { artifact } \\
\text { images processed; } \\
300 \text { video } \\
\text { transcriptions } \\
\text { created; data base } \\
\text { of } 300 \\
\text { artifacts created; } \\
\text { web site } \\
\text { and search engine } \\
\text { created based on } \\
\text { educator input and } \\
\text { in-house usability } \\
\text { testing }\end{array}$ & $\begin{array}{l}\text { All books assigned } \\
\text { reading levels; } 310 \text { podcasts created; } 100+ \\
\text { downloadable lesson plans/activities } \\
\text { developed by and provided for educators; } \\
132 \text { North Carolina Standard Course of } \\
\text { Study alignment correlations; } 300 \text { museum } \\
\text { artifact videos and podcasts; } 7 \text { teacher focus } \\
\text { groups, } 11 \text { regional teacher workshops and } 3 \\
\text { local workshops conducted; numerous } \\
\text { classroom lessons provided to schools; } \\
\text { Educator web portal designed; Learn NC } \\
\text { presence }\end{array}$ & $\begin{array}{l}\text { Classroom/ media center calendars and } \\
\text { posters; numerous promotional items } \\
\text { such as rulers, highlighters, and pens } \\
\text { with web address; bookmarks; Google } \\
\text { presence; } 4 \text { research articles published; } \\
1 \text { regional conference workshop and } 1 \\
\text { national pre-conference workshop; } 7 \\
\text { national, } 16 \text { regional/state and } 6 \text { local } \\
\text { conference presentations; exhibitions } \\
\text { at } 1 \text { national and } 2 \text { state conferences; } \\
\text { What's New--Monthly Feature" by } \\
\text { Learn NC }\end{array}$ \\
\hline
\end{tabular}

*** Winner of the $\mathbf{2 0 0 7}$ East Carolina University Centennial Award for Excellence

Seeds of Change: The Daily Reflector Image Collection (http://digital.lib.ecu.edu/reflector/)

\begin{tabular}{|l|l|l|l|l|}
\hline $\begin{array}{l}\text { Years } \\
\text { Awarded }\end{array}$ & Budget & Digitization & $\begin{array}{l}\text { Educational } \\
\text { Resources }\end{array}$ & $\begin{array}{l}\text { Promotion/ } \\
\text { Marketing }\end{array}$ \\
\hline $\begin{array}{l}\text { 2008- } \\
\text { M010 }\end{array}$ & $\mathbf{\$ 5 6 , 0 0 0 . 0 0}$ & $\begin{array}{l}7,500 \text { black and } \\
\text { white } \\
\text { Photographic images } \\
\text { from the local } \\
\text { newspaper, The } \\
\text { Daily Reflector, } \\
\text { covering 1947-1969 }\end{array}$ & $\begin{array}{l}\text { images available; searchable } \\
\text { historical themes; } \mathbf{1} \text { teacher } \\
\text { focus group; } \mathbf{1} \text { teacher } \\
\text { workshop; teacher web portal }\end{array}$ & $\begin{array}{l}\text { Bookmarks; classroom/ media center posters; two } \\
\text { research articles published; } 1 \text { national, 4 state and 3 } \\
\text { local conference presentations/exhibitions; } 2 \\
\text { opening receptions; numerous classroom lessons } \\
\text { provided to schools; Google presence; images } \\
\text { featured on MSNBC }\end{array}$ \\
\end{tabular}

*** Winner of the 2010 Gale Cengage Learning Award for Excellence in Reference and Adult Library Services Ensuring Democracy Through Digital Access: North Carolina Government Publications Collection (website under beta testing)

\begin{tabular}{|l|l|l|l|l|}
\hline $\begin{array}{l}\text { Years } \\
\text { Awarded }\end{array}$ & Budget & Digitization & $\begin{array}{l}\text { Educational } \\
\text { Resources }\end{array}$ & $\begin{array}{l}\text { Promotion/ } \\
\text { Marketing }\end{array}$ \\
\hline $\begin{array}{l}\mathbf{2 0 0 9 -} \\
\mathbf{2 0 1 1}\end{array}$ & $\mathbf{\$ 2 1 6 , 9 8 6 . 0 0}$ & $\begin{array}{l}\mathbf{2 , 3 0 0} \text { volumes of } \\
\text { historic state } \\
\text { publications from } \\
\text { 19th and 20th } \\
\text { centuries }\end{array}$ & $\begin{array}{l}\text { Downloadable access to } \\
\text { historic state publications for } \\
\text { classroom use available; 50+ } \\
\text { downloadable lesson } \\
\text { plans/activities } \\
\text { developed by and provided } \\
\text { for educators; 10-day teacher }\end{array}$ & $\begin{array}{l}\text { Projected for 2011: 2 national, 5 state conference } \\
\text { presentations/exhibitions and numerous local and } \\
\text { school presentations; bookmarks; classroom/ media } \\
\text { center posters; proposed research article for } \\
\text { publication }\end{array}$ \\
\hline
\end{tabular}


workshop provided

Appendix B

Sample Budget Request for a K-12 Educational Component of a Digitization Project/Grant

\begin{tabular}{|c|c|c|c|}
\hline Expenditure Category & Quantity & Cost per unit & Total \\
\hline \multicolumn{4}{|l|}{ Equipment } \\
\hline Laptop & 1 & $\$ 1,200.00$ & $\$ 1,200.00$ \\
\hline Data Projector & 1 & $\$ 2,000.00$ & $\$ 2,000.00$ \\
\hline Portable Screen & 1 & $\$ 50.00$ & $\$ 50.00$ \\
\hline Digital Camera & 1 & $\$ 150.00$ & $\$ 150.00$ \\
\hline \multicolumn{4}{|l|}{ Focus Group } \\
\hline Meals for Focus Group Attendees & $13 *$ & $\$ 10.00$ & $\$ 130.00$ \\
\hline Stipends for Attendees & 10 & $\$ 100.00$ & $\$ 1,000.00$ \\
\hline \multicolumn{4}{|l|}{ Teacher Workshop } \\
\hline Printing of Workshop Materials & & $\$ 500.00$ & $\$ 500.00$ \\
\hline Stipends (10 teachers X 10 days) & 100 & $\$ 100.00$ & $\$ 10,000.00$ \\
\hline \multicolumn{4}{|l|}{ Substitute Pay** } \\
\hline Travel (10 teachers X 2 trips)**** & 20 & $\$ 200.00$ & $\$ 4,000.00$ \\
\hline State of NC Per Diem (10 teachers X 10 days)***** & 100 & $\$ 101.05$ & $\$ 10,105.00$ \\
\hline \multicolumn{4}{|l|}{ Personnel } \\
\hline Focus Group Moderator & 1 & $\$ 500.00$ & $\$ 500.00$ \\
\hline $\begin{array}{r}\text { Master Teacher to conduct Workshop (10 } \\
\text { weeks) } * * * * *\end{array}$ & 10 & $\$ 917.00$ & $\$ 9,170.00$ \\
\hline \multicolumn{4}{|l|}{ Marketing/Promotion } \\
\hline Registration for 3 Conferences & 2 & $\$ 500.00$ & $\$ 1,000.00$ \\
\hline Vendor/Exhibitor fees & 3 & $\$ 1,400.00$ & $\$ 4,200.00$ \\
\hline State of NC Per Diem (In-state) & 12 & $\$ 101.05$ & $\$ 1,212.60$ \\
\hline State of NC Per Diem (Out-of-state) & 12 & $\$ 115.55$ & $\$ 1,386.60$ \\
\hline Hotel Accommodations & 24 & $\$ 200.00$ & $\$ 4,800.00$ \\
\hline Travel by Airfare******* & 2 & $\$ 400.00$ & $\$ 800.00$ \\
\hline \multicolumn{4}{|l|}{ Other expenses } \\
\hline 2 GB USB drives for workshop & 15 & $\$ 10.00$ & $\$ 150.00$ \\
\hline Total Project Costs & & & $\$ 52,354.20$ \\
\hline
\end{tabular}

*Includes 10 participants, 1 moderator, and 2 note-takers.

**:Please note that if workshop is held during school hours, allocations must include substitute pay at the rate of $\$ 90.00$ per participant per day. To eliminate these costs, plan workshop during summer months when teachers are not in the classroom.

****Participants will receive mileage reimbursement to cover travel for two round trips.

****NC Per Diem (in-state) is $\$ 101.05$ per day. Adjust accordingly based on state.

*****Master teacher will organize, develop and facilitate the workshop. This person will also review and edit all lesson activities prior to placement on website. Based on salary of $\$ 47,690 /$ year.

******One conference travel will be via university van. 